\title{
The Lunar Series and eclipse cycles at Palenque, Chiapas, Mexico
}

\author{
Stanislaw Iwaniszewski
}

\begin{abstract}
A great number of Maya hieroglyphic texts consisted of a series of dated events connected by counts of days between them. These counts of days were represented by so-called Distance Numbers (hereafter DNs), which added or subtracted specific numbers of days to link important dates and associated events. On certain occasions, the intervals represented by the DNs conformed to numerical-calendric or astronomical cycles. The Maya timekeepers of Palenque used DNs representing the multiples of 11960 days, which identified with the Dresden Codex Eclipse Table seem to evoke eclipse cycles. In this paper, I will argue that they should be treated as intervals to compute the Lunar Series rather than eclipse cycles.
\end{abstract}

Keywords: Lunar Series, Eclipse Cycles, Maya Astronomy, Palenque

\begin{abstract}
Resumen
LAS SERIES LUNARES Y LOS CICLOS DE ECLIPSES EN PALENQUE, CHIAPAS, MÉXICO

Gran número de los textos jeroglíficos mayas registran una serie de eventos fechados conectados por la un cadena de cuenta de días entre ellos. Estos recuentos de días estaban representados por los llamados números de distancia (en adelante ND), que sumaban o restaban cantidades específicas de días para vincular fechas importantes y eventos asociados. En determinadas ocasiones, los intervalos representados por los ND se ajustaban a los ciclos numérico-calendáricos o astronómicos. Los especialistas del calendario mayas de Palenque utilizaron los ND que expresaron los múltiplos de 11960 días que identificados con la Tabla de Eclipses del Códice de Dresde parecen evocar los ciclos de eclipses. En este artículo, argumentaré que dichos múltiplos de 11960 días deben tratarse más bien como los intervalos para calcular la Serie Lunar y no como los el cómputo de los ciclos de eclipses.
\end{abstract}

Palabras clave: Series Lunares, ciclos de eclipses, astronomía maya, PalenquePalabras clave: maya clásico, concepto de espacio, descripción topológica semántica, verbos de movimiento, marcos de referencia.

Stanisław Iwaniszewski - Posgrado en Arqueología, Escuela Nacional de Antropología e Historia Instituto Nacional de Antropología e Historia, México. siwanisz@yahoo.com

(D) https://orcid.org/ 


\section{Introduction}

As is known, Distance Numbers fixed the intervals of days linking the dates of relevant events in the lives of Maya rulers. At Palenque, the scribes occasionally reckoned larger DNs connecting historical events with those believed to happen deep in the mythological past. In this case, the number of days between the current and ancient events almost inevitably implied the invention of an imaginary date, and hence could have easily been subject to various numerical-calendar manipulations. In a series of papers, Floyd Lounsbury $(1974,1976,1978,1980)$ proposed that some of Palenque DNs might have been contrived to accommodate specific numerological-calendrical or astronomical patterns. These so-called "contrived numbers" included intervals functioning as the multiples of the significant calendrical numbers (such as $7,9,13,260$, and 819) and astronomical cycles. In other words, those DNs not only recorded the days that had elapsed since the mythological dates but also accommodated them to the numerological patterns required by local circumstances. Numerology played an essential role in the legitimation practices of the rulers (Schele and Freidel 1990: 223-224).

Lounsbury's initial study was followed by Gerardo Aldana (2007), who ascribed the invention of the 819-day count to the scribes acting in the court of Janaab Pakal $^{1}$ (615-683) and his elderly son and successor Kan Bahlam II (684-702). Aldana proposed that both rulers produced long narratives describing the mythical origins of the patron gods of Palenque (the so-called Palenque Triad, Berlin 1963; Stuart and Stuart 2008: 189-215) occurring on specifically generated dates. Calendrical and astronomical cycles attached to mythological and current cycles enabled both rulers to integrate their dynasty within the mythological-historical narrative about the divine origins of their kingdom. The purpose was to revert the disastrous effects of the defeat of Palenque (and its ruling house) by Calakmul in the early 7th century.

John Teeeple (1931), who worked out the basic elements of the Lunar Series, offered the keys to understanding Mayan lunar computations. After examining lunar dates attached to the Initial Series at Palenque, he inferred that the scribes computed moon phases equaling the length of 81 lunations to the period of 2392 days, giving a synodic month of 29.5308642 days. Teeple's discovery provided connections with the Dresden Codex because five times 2392 days gives 11960 days, the length of its eclipse table. Further examination of lunar numerology suggests that the lunar cycle might have been a significant factor in the DNs found in Palencan texts, not only in the form of DNs divisible by 2392 but also by 11960 days (e.g., Lounsbury 1976: 220-221; 1978: 775, 808; Stuart 2005: 77). It turns out that some of the lengthy DNs not only commensurate with the Palenque lunar formula but also with the Dresden Codex eclipse cycle.

This turns naturally to the question of whether the DNs from Palenque contain dates representing eclipse cycles. The affirmative answer might suggest that 
the city's scribes were able to predict eclipses, indicating that the eclipse cycle was intended to be recycled. However, It appears the dates given in the texts cannot be associated with any eclipse seasons. This is why Lounsbury (1978:808) considers this cycle as merely "numerological." Hence, if the placing of the multiples of 11960 days was not expected to forecast eclipse possibilities in the deep past, one can ask what the practical, not symbolic reason for the installation of this cycle in the DNs was. The purpose of this paper is to determine whether this cycle could have been applied to perform lunar computations or to predict eclipse possibilities.

\section{Maya Lunar Count}

The Maya counted the Moon from the moment when the lunar crescent was first sighted in the western sky just after the sunset. More detailed studies of Glyphs D and E in Piedras Negras, Yaxchilán, Quiriguá, and Copán (Iwaniszewski 2004, 2007) show that this was not always a case, and the month could have begun as well during Moon's invisibility. The first visibility of the lunar crescent was probably referred to as arriving, huli, to the sky. Though there is no evidence that the ancient Maya had a formal lunar calendar like in the ancient Near East or China, we know they created a complex system of recording lunar months known as the Lunar Series. The whole series consisted of six signs labeled as Glyphs A, B, X, C, D, E, which provided information on the lunar month, number of the current lunar month in a series of six and eighteen, and the expected length of the current lunar month.

Glyphs E and D indicated the number of days elapsed after the Moon's first visibility, and we can safely interpret her arrival to the sky as referring to her first visibility.

FIGURE 1. Numerical coefficients combined with the lunar patrons of Glyph C to denote eighteen different lunations (lunar synodic months): s-skull (Death God), m - Maize God, j - Jaguar God of the Underworld.

\begin{tabular}{|c|c|c|}
\hline Group I & Group II & Group III \\
\hline $1 \mathrm{Cs}$ & & \\
\hline $2 \mathrm{Cs}$ & $1 \mathrm{Cm}$ & $1 \mathrm{Cj}$ \\
\hline $3 \mathrm{Cs}$ & $2 \mathrm{Cm}$ & $2 \mathrm{Cj}$ \\
\hline $4 \mathrm{Cs}$ & $3 \mathrm{Cm}$ & $3 \mathrm{Cj}$ \\
\hline $5 \mathrm{Cs}$ & $4 \mathrm{Cm}$ & $4 \mathrm{Cj}$ \\
\hline $6 \mathrm{Cs}$ & $5 \mathrm{Cm}$ & $5 \mathrm{Cj}$ \\
\hline 6 lunar months & $6 \mathrm{Cm}$ & $6 \mathrm{Cj}$ \\
\hline 18 lunar months & 6 lunar months & 6 lunar months \\
\hline
\end{tabular}


The Maya grouped sequences of lunar months in sets of six and eighteen (see Figure 1). The six and eighteen-month groupings were produced through the variable components of Glyph C, the numerical coefficients varying from 1 to 6 and three head variants: a skull (God A, or a Death God) (s), head of a maize god (Tonsured Maize God, called Juun Ixiim) (m), and head of the Jaguar God of the Underworld (j). The sequence of head variants followed the same fixed order producing a total of 18 different forms of Glyph $\mathrm{C}^{2}$.

To avoid problems with the continuous observation of the first visibility of the Moon (due to weather conditions), Mayan timekeepers adopted the schematic lunar count with alternating 30-day and 29-day lunar months. They started this method between the fourth and fifth centuries when they first incorporated Glyph A into the Lunar Series. Glyph A defined whether the month was 29 or 30 days long, ignoring any consideration of the actual month. According to Teeple (1931: 63), the incorporation of Glyph A into the Lunar Series marked attempts made by the Maya scribes to control the lunar count. This invention was a critical step in the development of the Mayan Lunar Theory. It served to develop a more abstract, numerological, or "arithmetic" system of predicting the lunar phase, being less dependent on direct observations. Consequently, six lunar months always amounted to 177 or 178 days, enabling eclipse predictions by merely counting days (see Figure 2).

It might be argued that by grouping sequences of lunar months in groups of six and five, ancient timekeepers were attempting to forecast eclipses with appropriate accuracy. Such a statement is justified on astronomical grounds because there is a close equivalence between the period of six lunar synodic months and the eclipse half-year. However, in my opinion, this is not the sole reason for ancient timekeepers to develop six- and five-month sequences. Aside from their relationship to eclipse forecast, the six-month groups may also result from the necessity to adjust the lunar count to the year. The scheme of six-month groups fitted into the frame provided by the solstices is also functional to avoid the discrepancy of the lunar cycle with the seasonal year. Since it is not possible to maintain each group of six lunar months within each year-half for a longer time, this scheme may be used as the means to avoid a further slippage between solar and lunar cycles.

The institution of a fixed lunar count, with alternating 30-day and 29-day lunar months, might provide a background necessary to the development of various schemes of intercalation (Satterthwaite 1947: 86-106; Lounsbury 1978: 85-91). This intercalation could be accomplished through the substitution of a 29-day month with that of 30 days. However, by raising a 29 -day month to a 30 -day month, the regular arrangement of 29-day and 30-day months was affected. This fact is revealed through the series of 6 months. Because the ordinary lunar semester consisted of 177 days (three months of 29 days and three of 30 days), the occurrence of 178-day semesters is indicative of this kind of adjustment (four months of 30 days plus two months of 29 days). The lunar count could follow a regular pattern, such as the 4784 - 
FIGURE 2. Hypothetical semesters patronized by Glyph C head variants linked to an alternating Glyph A numerical coefficients. Two alternative sequences (starting either with a 30-day Glyph A or with a 29-day Glyph A) are displayed. Head variants: s - skull (Death God), $\mathrm{m}$ - Maize God, $\mathrm{j}$ - Jaguar God of the Underworld.

\begin{tabular}{|l|l|l|l|l|r|}
\hline \multicolumn{2}{|c|}{ Group I: starts with a 30-day schematic } & \multicolumn{3}{c|}{ Group II: starts with a 29-day schematic } \\
lunar month
\end{tabular}

day cycle of intercalations known from the Lunar Table from Xultun. The table is painted on the wall of a small room and is composed of 27 columns representing lunar semesters of 177 and 178 days registered in the Maya numerical bar-and-dot system (see Figure 3).

The table represents a sequence of the three Glyph $\mathrm{C}$ head variants topped each of the 27 columns (see Figure 4). The table starts with a kind of preamble consisting of two columns representing a regular sequence of 12 alternating 30-day and 29-day months, making up of 354 days, or one lunar year. Following this, there is

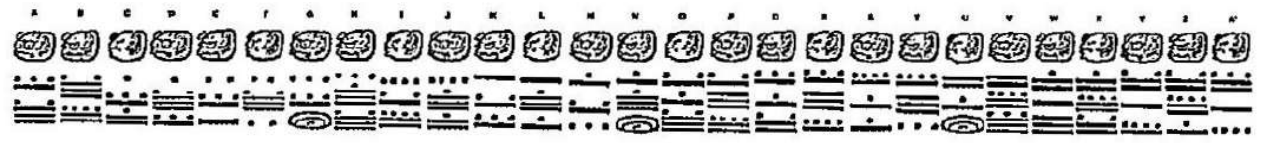

Figure 3. A reconstruction of the Lunar Table from Xultun. Drawing after D. Stuart

(Saturno et al. 2012: S6, Figure S3).

\begin{tabular}{|c|c|c|c|c|c|c|c|c|c|c|c|c|c|c|c|c|c|c|c|c|c|c|c|c|c|c|}
\hline $\mathrm{J}$ & $\mathrm{S}$ & $\mathrm{M}$ & $\mathrm{J}$ & $\mathrm{S}$ & $\mathrm{M}$ & $\mathrm{J}$ & $\mathrm{S}$ & $\mathrm{M}$ & $\mathrm{J}$ & $\mathrm{S}$ & $\mathrm{M}$ & $\mathrm{J}$ & $\mathrm{S}$ & $\mathrm{M}$ & $\mathrm{J}$ & $\mathrm{S}$ & $\mathrm{M}$ & $\mathrm{J}$ & $\mathrm{S}$ & $\mathrm{M}$ & $\mathrm{J}$ & $\mathrm{S}$ & $\mathrm{M}$ & $\mathrm{J}$ & $\mathrm{S}$ & $\mathrm{M}$ \\
\hline 1 & 1 & 1 & 1 & 1 & 1 & 1 & 1 & 1 & 1 & 1 & 1 & 1 & 1 & 1 & 1 & 1 & 1 & 1 & 1 & 1 & 1 & 1 & 1 & 1 & 1 & 1 \\
7 & 7 & 7 & 7 & 7 & 7 & 7 & 7 & 7 & 7 & 7 & 7 & 7 & 7 & 7 & 7 & 7 & 7 & 7 & 7 & 7 & 7 & 7 & 7 & 7 & 7 & 7 \\
7 & 7 & 7 & 7 & 7 & 7 & 8 & 7 & 7 & 7 & 7 & 8 & 7 & 7 & 7 & 7 & 8 & 7 & 7 & 7 & 7 & 8 & 7 & 7 & 7 & 7 & 8 \\
\hline 354 & \multicolumn{10}{|c|}{886} & \multicolumn{10}{|c|}{886} & \multicolumn{10}{|c|}{886} & \multicolumn{6}{|c|}{886} \\
\hline
\end{tabular}

FIGURE 4. Transcription of the calendrical count of the Xultun Lunar Table. Cumulative numbers 354 and 886 are not given in the table, they are included for the convenience of the reader. Labels:

J- Jaguar God of the Underworld, S - Skull, M - Tonsured Maize God. 
a sequence of four columns representing 177 days each, ended with a fifth column with 178 days, in total 886 days. This configuration repeats five times, to account for 4430 days. Here, each intercalary day is preceded or followed by a period of 886 days. In total, the table yields 4784 days and 162 months, doubling the number of the days and months with the Palenque formula.

\section{Maya eclipse cycles}

Like many other peoples, Mayan timekeepers attempted to understand the irregular occurrences of solar and lunar eclipses. Their so-called Eclipse Table from the Dresden Codex shows that to forecast eclipses accurately, they were keeping track of eclipse periodicities over many decades or centuries. Without understanding what caused eclipses ${ }^{3}$, Mayan timekeepers made eclipse predictions using the modified triple 135-month recurrence period because it agreed pretty well with forty-six revolutions of their 260-day tzolk'in:

$3 \times 135$ lunar months $=405$ lunar months $=46 \times 260$ tzolk'ins $=11960$ days

However, though they purposefully assembled the Eclipse Table to identify the dates of eclipse possibilities, they did not leave any actual record of eclipse observations $s^{4}$. Consequently, the texts do not suffice to say how the Mayan timekeepers treated the eclipses that they could not observe, nor how their scheme for predicting eclipses was brought into use ${ }^{5}$.

\section{The Structure of the Dresden Codex Eclipse Table}

The structure of the table may be seen most clearly in Bricker and Bricker (2011: 257-261). The proper table extends from Dresden 53a to Dresden 58b and can be divided into the upper (from D53a to D58a) and lower (from D51b to D58b) parts (see Figure 5). The table consists of 69 columns of numbers displayed in the system of bar-and-dot numerals; below each column, there are three tzolk'in day signs with numerical coefficients. Additional hieroglyphic notations for columns and pictures are placed above.

Each column represents an interval of 6 (177 or 178 days) or 5 (148 days) lunar months, yielding a total of 11959 days or 405 lunar months. This result is erroneously written as 11958 days in column 69. All nine intervals of 148 days precede pictures which seem to denote eclipse possibilities. Only the tenth picture, attached to the end of the table (D58b), is following a 177-day interval. In total, there are sixty 6-month and nine 5-months intervals (see Figure 6).

The Mayan timekeepers realized that the arrangement of eclipse possibilities in these 405 months not only repeated over and over but also coincided with the multiples of 260-day tzolk'in. Within each period of 405 synodic months, the 69 eclipse possibilities are divided into 60 at 6 -month intervals, and the remaining 


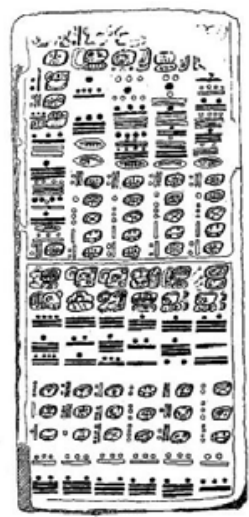

51

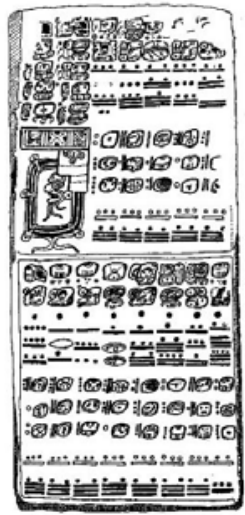

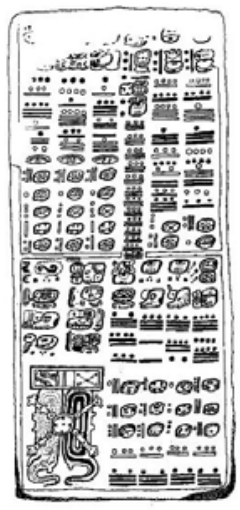

52

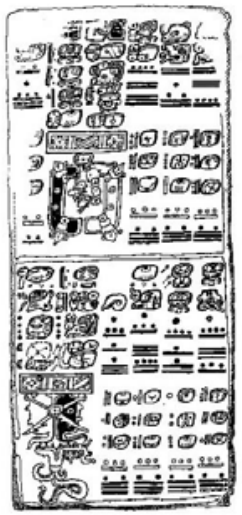

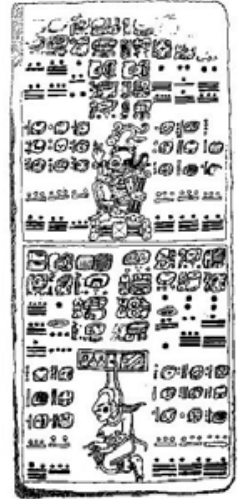

53

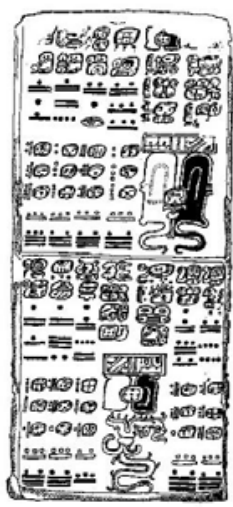

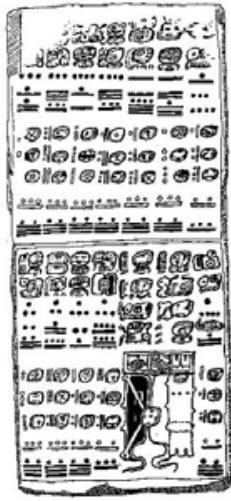

54

Figure 5. The Eclipse Table of the Dresden Codex (after Villacorta and Villacorta 1930: 112, 114, 116, $118,120,122,124,126)$.

9 at 5-month intervals. They all fall into nine groups, meaning that groups one and ten can be arranged together. Thus, the 69 eclipse possibilities are divided into nine groups, each of which ends with an 5-month interval. These groups are identified as containing, 10, 6, 7, 10, 6, 7, 9, 7, 7 eclipses possibilities respectively (compare Figure 6). After repeating each cycle of 405 months, it is possible to forecast eclipse possibilities again. They further may be converted into three groups, each containing 23 eclipse possibilities. Each of those three groups contains 135 lunar months $(20 \times 6+3 \times 5=135)$. It is tempting to suggest that Mayan timekeepers made use of the eclipse cycle of 135 months, called Tritos, to forecast eclipses. Using the fact that there 23 eclipse possibilities within the 135 months (Guthe 1921), they combined three modified Tritos cycles to synchronize eclipse predictions with forty-six tzolk'in cycles. In this connection, scholars who examined the table offered two alternative explications of the Mayan methods of prediction: the dates from the Dres- 
den Eclipse Table signal, either the dates of eclipse possibilities or eclipse seasons (consult Justeson 2017: 508). The divergence of opinions is probably because the dates of eclipse possibilities do not always meet with the dates when the Moon or the Sun are closest to the node.

\begin{tabular}{|c|c|c|c|c|c|c|c|c|c|c|c|c|c|c|c|c|c|c|c|c|c|c|c|c|c|}
\hline \multicolumn{5}{|l|}{$53 a$} & \multicolumn{7}{|c|}{$54 a$} & \multicolumn{5}{|c|}{$55 a$} & \multicolumn{4}{|c|}{$56 a$} & \multicolumn{5}{|c|}{$57 \mathrm{a}$} \\
\hline 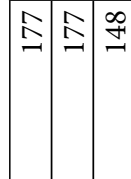 & 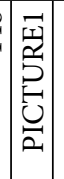 & 尺 & 신 & હ & 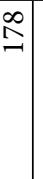 & 성 & 全 & 弆 & 今 & $\underline{\Delta}$ & $\begin{array}{l}\infty \\
\pm \\
+\end{array}$ & 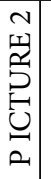 &  & 令: & 今 & 令 & 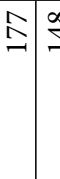 & 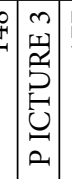 & 속 &  & $=\stackrel{\infty}{=}$ & 尺 & 全 & \begin{tabular}{l|}
$\infty$ \\
\pm \\
\pm
\end{tabular} &  \\
\hline & $58 \mathrm{a}$ & & & & & $51 \mathrm{~b}$ & & & & & & $52 \mathrm{~b}$ & & & & & $53 b$ & & & & $54 \mathrm{~b}$ & & & & \\
\hline &  & 尽 & 시 & 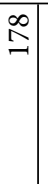 & $\underline{\Delta}$ & 令 & 全 & 全 & 신 & 싱. & $\begin{array}{l}\infty \\
\pm \\
+ \\
\end{array}$ & 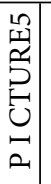 & $\stackrel{\infty}{\infty}:$ & 令: & 尽 & 今 & 全政 & 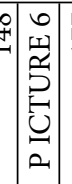 & 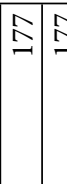 & 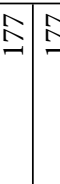 & $=N$ & & & & 武 \\
\hline & $54 \mathrm{~b}$ & & $55 \mathrm{~b}$ & & & & & & & & $56 \mathrm{~b}$ & & & & & $57 \mathrm{~b}$ & & & & 58 & $8 \mathrm{~b}$ & & & & \\
\hline & 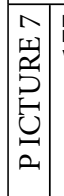 & 손 & \begin{tabular}{l|}
$\infty$ \\
$\stackrel{0}{\sim}$
\end{tabular} & 시 & 슨 & $\underline{\underline{\lambda}}$ & 시 & 令 & 슷 & $\stackrel{\infty}{+}$ & 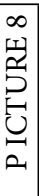 & 신 & & 今 & 全 & 今 & 全 & 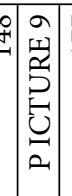 & & & 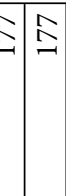 & 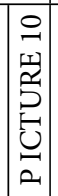 & & & \\
\hline
\end{tabular}

FIGURE 6. Transcription of the calendrical count in the 69 columns of the Eclipse Table.

According to most scholars, the table starts with the base date of 9.16.4.10.8 12 Lamat [1 Muan]. This is one of four dates, arranged in two columns, displayed on page D52a, just before the Eclipse Table. The same date, [9].16.4.10.8 12 Lamat [1 Muan], also constitutes one of two base dates of the table, on page 51a (Bricker and Bricker 2011: 251-254, 275-301). By counting forward 177 days, one arrives at the date of [9.16.5.1.5] 7 Chicchan [13 Tzek] (see Figure 7). The day 7 Chicchan is found in the middle of three successive tzolk'in dates (6 Kan, 7 Chicchan, and $8 \mathrm{Cimi}$ ) on D53a (see Figure 8). The table then continues forward by another interval of 177 days to reach [9.16.5.10.2] $2 \mathrm{Ik}$ [10 K'ank'in]. Again, this date may be found in the middle of three successive tzolk'in days (1 Imix, 2 Ik $3 \mathrm{Akbal}$ ). Finally, the table ends with [ 9.17.17.14.7] 11 Manik [15 Yax] day displayed in the middle of three tzolk'in dates (10 Cimi, 11 Manik, 12 Lamat) on D58b, thus covering 11959 days. Naturally, one day later, after the completion of 11960 days, the count returns to a 12 Lamat day (that is, to [9.17.17.14.8] 12 Lamat [16 Yax]).

Now, if the table were recycled and continued by again counting forward 177 days, it would arrive at [9.17.18.5.4] 6 Kan [7 Pop], the day that is found at the bottom of three tzolk' in dates on D52a (see Figure 7). After the whole cycle, the table would end with the date of [9.19.11.0.6] 10 Cimi [9 Xul]. With each run of the table, the tzolk' in day would retrocede one or two days, for example, 12 Lamat $\rightarrow 11$ 
FIGURE 7. Transcription of the calendrical count in the Eclipse Table. The dates are counted from 9.16.4.10.8 12 Lamat [1 Muan] which is displayed on D52a prior to the Eclipse Table.

\begin{tabular}{|c|c|c|c|}
\hline-4 & [9.16.2.11.0] 6 ahaw [3 pax] & Imagen & \\
\hline-3 & [9.16.3.1.17] 1 kaban [15 xul] & & -177 \\
\hline-2 & [9.16.3.10.14] 9 ix [12 muan] & & -177 \\
\hline-1 & [9.16.4.1.11] 4 chuwen $[4 \mathrm{xul}]$ & & -177 \\
\hline 0 & 9.16.4.10.8 12 lamat [1 muan] & & -177 \\
\hline 0 & 9.16.4.10.8 12 lamat [1 muwan] & & +177 \\
\hline 1 & [9.16.5.1.5] 7 chikchan [13 tzek] & & +177 \\
\hline 2 & [9.16.5.10.2] 2 ik' [10 k'ank'in] & & +148 \\
\hline 3 & [9.16.5.17.10] 7 ok [13 sip] & Imagen & +177 \\
\hline 4 & [9.16.6.8.7] 2 manik [10 keh] & & +177 \\
\hline 5 & [9.16.6.17.4] 10 k’an [2 sip] & & +177 \\
\hline 6 & [9.16.7.8.1] 5 imix [19 sak] & & +178 \\
\hline 7 & [9.16.7.16.19] 1 kawak [12 woh] & & +177 \\
\hline 8 & [9.16.8.7.16] $9 \mathrm{kib}[9 \mathrm{sak}]$ & & +177 \\
\hline 9 & [9.16.8.16.13] 4 ben [ 1 woh] & & +177 \\
\hline 10 & [9.16.9.7.10] $12 \mathrm{ok}[18 \mathrm{yax}]$ & & +177 \\
\hline 11 & [9.16.9.16.7] 7 manik [10 pop] & & +177 \\
\hline 12 & [9.16.10.7.4] 2 k'an [7 yax] & & +148 \\
\hline 13 & [9.16.10.14.12] 7 eb [15 k'ayab] & Imagen & +178 \\
\hline 14 & [9.16.11.5.10] $3 \mathrm{ok}[8 \mathrm{~mol}]$ & & +177 \\
\hline 15 & [9.16.11.14.7] 11 manik [5 k’ayab] & & +177 \\
\hline 16 & [9.16.12.5.4] 6 k'an [17 yaxk'in] & & +177 \\
\hline 17 & [9.16.12.14.1] 1 imix [14 pax] & & +177 \\
\hline 18 & [9.16.13.4.18] 9 etz'nab [6 yaxk'in] & & +148 \\
\hline 19 & [9.16.13.12.6] 1 kimi [14 k’ank’in] & Imagen & +177 \\
\hline 20 & [9.16.14.3.3] 9 ak’bal [6 tzek] & & +177 \\
\hline 21 & [9.16.14.12.0] 4 ahaw [3 k'ank'in] & & +177 \\
\hline 22 & [9.16.15.2.17] 12 kaban [15 sotz'] & +177 & +178 \\
\hline 23 & [9.16.15.11.15] 8 men [13 mak] & & +177 \\
\hline 24 & [9.16.16.2.12] 3 eb [5 sotz'] & & +177 \\
\hline 25 & [9.16.16.11.9] 11 muluk [2 mak] & & +148 \\
\hline 26 & [9.16.17.0.17] 3 kaban [5 woh] & Imagen & +177 \\
\hline 27 & [9.16.17.9.14] $11 \mathrm{ix}$ [2 sak] & & +177 \\
\hline 28 & [9.16.18.0.11] 6 chuwen [14 pop] & & +178 \\
\hline 29 & [9.16.18.9.9] 2 muluk [12 yax] & & +177 \\
\hline 30 & [9.16.19.0.6] 10 kimi [4 pop] & & +177 \\
\hline 31 & [9.16.19.9.3] 5 ak'bal [1 yax] & & +177 \\
\hline 32 & [9.17.0.0.0] 13 ahaw [18 kumk'u] & & +177 \\
\hline 33 & [9.17.0.8.17] 8 kaban [10 ch'en] & & +177 \\
\hline
\end{tabular}




\begin{tabular}{|c|c|c|c|}
\hline 34 & [9.17.0.17.14] 3 ix [7 kumk'u] & & +177 \\
\hline 35 & [9.17.1.8.11] 11 chuwen $[19 \mathrm{~mol}]$ & & +148 \\
\hline 36 & [9.17.1.15.19] 3 kawak [7 pax] & Imagen & +178 \\
\hline 37 & [9.17.2.6.17] 12 kaban 0 yaxk'in & & +177 \\
\hline 38 & [9.17.2.15.14] 7 ix [17 muan] & & +177 \\
\hline 39 & [9.17.3.6.12] 3 eb [10 xul] & & +177 \\
\hline 40 & [9.17.3.15.8] 10 lamat [6 muan] & & +177 \\
\hline 41 & [9.17.4.6.5] 5 chikchan [18 tzek] & & +148 \\
\hline 42 & [9.17.4.13.13] 10 ben [6 mak] & Imagen & +177 \\
\hline 43 & [9.17.5.4.10] 5 ok [18 sip] & & +177 \\
\hline 44 & [9.17.5.13.7] 13 manik [15 keh] & & +177 \\
\hline 45 & [9.17.6.4.4] 8 k'an [7 sip] & & +177 \\
\hline 46 & [9.17.6.13.1] 3 imix [4 keh] & & +177 \\
\hline 47 & [9.17.7.3.18] 11 etz'nab [16 woh] & & +177 \\
\hline 48 & [9.17.7.12.15] 6 men [13 sak] & & +148 \\
\hline 49 & [9.17.8.2.3 11] ak'bal [1 wayeb] & Imagen & +177 \\
\hline 50 & [9.17.8.11.0] 6 ahaw [13 chen] & & +177 \\
\hline 51 & [9.17.9.1.17] 1 kaban [10 kumk'u] & & +178 \\
\hline 52 & [9.17.9.10.15] 10 men [ 3 chen] & & +177 \\
\hline 53 & [9.17.10.1.12] 5 eb [0 kumk'u] & & +177 \\
\hline 54 & [9.17.10.10.9] 13 muluk [12 mol] & & +177 \\
\hline 55 & [9.17.11.1.6] 8 kimi [9 k’ayab] & & +177 \\
\hline 56 & [9.17.11.10.3] 3 ak'bal [1 mol] & & +177 \\
\hline 57 & [9.17.12.1.0] 11 ahaw [18 pax] & & +148 \\
\hline 58 & [9.17.12.8.8] 3 lamat [1 xul] & Imagen & +177 \\
\hline 59 & [9.17.12.17.5] 11 chikchan [18 k'ank'in] & & +178 \\
\hline 60 & [9.17.13.8.2] 7 ak'bal [11 tzek] & & +177 \\
\hline 61 & [9.17.13.17.0] 2 ahaw [8 k’ank'in] & & +177 \\
\hline 62 & [9.17.14.7.17] 10 kaban [0 tzek] & & +177 \\
\hline 63 & [9.17.14.16.14] 5 ix [17 mak] & & +177 \\
\hline 64 & [9.17.15.7.11] 13 chuwen [9 sotz'] & & +148 \\
\hline 65 & [9.17.15.14.19] 5 kawak [17 sak] & imagen & +177 \\
\hline 66 & [9.17.16.5.16] $13 \mathrm{kib}$ [9 woh] & & +177 \\
\hline 67 & [9.17.16.14.13] 8 ben [6 sak] & & +177 \\
\hline 68 & [9.17.17.5.10] 3 ok [18 pop] & & +177 \\
\hline 69 & [9.17.17.14.7] 11 manik [15 yax] & Imagen & +177 \\
\hline 70 & [9.17.18.5.4] 6 k'an [7 pop] & & +177 \\
\hline 71 & [9.17.18.14.1] 1 imix [4 yax] & & +148 \\
\hline 72 & [9.17.19.3.9] 6 muluk [12 k’ayab] & Imagen & +177 \\
\hline 73 & [9.17.19.12.6] 1 kimi [4 mol] & & +177 \\
\hline 74 & [9.18.0.3.3] 9 ak'bal [1 k’ayab] & & +177 \\
\hline
\end{tabular}


Manik $\rightarrow 9$ Chicchan, etcetera, the phenomenon described as „the recession of the eclipse seasons through the tzolk' in" (Bricker and Bricker 2011: 292). The eclipse cycle falls short of the 11960 days by 1.61 days, so without the knowledge of the appropriate corrective mechanism, it seems questionable to conceive of the uncorrected 11960-day cycle as an efficient eclipse predictor applied to DNs. Bricker and Bricker (2011: 292-301), however, have demonstrated that the utility of the table could be maintained for several centuries if the Maya scribes would implement the appropriate corrective mechanism. It is not known, however, whether the timekeepers subscribed to the same or similar methods for recycling the multiples of 11960 days in DNs. So, while there may be some DNs contrived to commensurate intervals of 11960 days, none of them in themselves seem to accurate enough to recycle eclipse cycles. If such corrective mechanism ever functioned in the context of monumental inscriptions, it has yet to be identified.

\begin{tabular}{|c|c|c|c|c|c|c|c|}
\hline $53 a$ & & & & $57 \mathrm{~b}$ & $58 \mathrm{~b}$ & & \\
\hline 177 & 354 & 502 & \multirow{3}{*}{$\begin{array}{l}\text { PICTURE } \\
1\end{array}$} & 11605 & 11782 & 11959 & \multirow{3}{*}{$\begin{array}{l}\text { PICTURE } \\
10\end{array}$} \\
\hline $\begin{array}{l}6 \text { Kan } \\
7 \text { Chic- } \\
\text { chan } 8 \\
\text { Cimi }\end{array}$ & $\begin{array}{l}1 \text { Imix } \\
2 \text { Ik } \\
3 \text { Akbal }\end{array}$ & $\begin{array}{l}6 \text { Muluc } \\
7 \text { Oc } \\
8 \text { Chuen }\end{array}$ & & \begin{tabular}{|l}
$7 \mathrm{~Eb}$ \\
$8 \mathrm{Ben}$ \\
$9 \mathrm{Ix}$
\end{tabular} & $\begin{array}{l}2 \text { Muluc } \\
3 \text { Oc } \\
4 \text { Chuen }\end{array}$ & $\begin{array}{l}10 \text { Cimi } \\
11 \text { Manik } \\
12 \text { Lamat }\end{array}$ & \\
\hline 177 & \begin{tabular}{|l|}
177 \\
\end{tabular} & 148 & & 177 & 177 & \begin{tabular}{|l|}
177 \\
\end{tabular} & \\
\hline
\end{tabular}

FIGURE 8. Transcription of the start and end of the Dresden Eclipse Table. For the sake of place, are displayed only three starting columns from D53a, and three ending columns from D58b.

\section{Eclipse Periods and Lunar Synodic Cycles}

The period of 405 synodic months is very close to 439.5 draconitic months, which means the recurring eclipses will occur at different lunar nodes. The period of 405 synodic months also corresponds to 46 cycles of a tzolk' in. Relations among integral numbers of tzolk' ins, synodic, and draconitic months are clear and sufficiently accurate (see Figure 9). In contrast with them, the difference between 405 synodic months and eclipse cycles is about a day and a half, it is much higher than the former case, so some corrective mechanisms should necessarily be applied. The accumulation of shorfall in eclipse cycles is much quicker that it does in lunar synodic cycles (Lounsbury 1978: 796-797; Bricker and Bricker 2011: 289-292).

It is, therefore, important to highlight the commensuration of a 11960-day cycle to the lunar synodic period. In the absence of direct eclipse corrective rules in DNs, the usefulness of this period to compute lunar phases may be examined. To start with, I propose to analyze the pattern of intercalary days in the Dresden Eclipse Table. 


\begin{tabular}{|l|c|c|c|c|}
\hline \multicolumn{1}{|c|}{ Period } & $\begin{array}{c}\text { Length } \\
\text { (days) }\end{array}$ & Cycles & Days & $\begin{array}{c}\text { Difference between 11960 } \\
\text { days and a given period } \\
\text { (days) }\end{array}$ \\
\hline Tzolk'in (260-day cycles) & 260 & 46 & 11960 & 0 \\
\hline $\begin{array}{l}\text { Synodic months (new moon to } \\
\text { new moon) }\end{array}$ & 29.530589 & 405 & 11959.889 & 0.11145 \\
\hline $\begin{array}{l}\text { Draconitic months (node to } \\
\text { node) }\end{array}$ & 27.212221 & 439.5 & 11959.771 & 0.22887 \\
\hline $\begin{array}{l}\text { Anomalistic months (perigee to } \\
\text { perigee) }\end{array}$ & 27.55455 & 434 & 11958.6747 & 1.3253 \\
\hline $\begin{array}{l}\text { Eclipse half-years (node to node } \\
\text { along the ecliptic) solar eclipses }\end{array}$ & 373.31 & 69 & 11958.39 & 1.61 \\
\hline
\end{tabular}

FIGURE 9. Some lunar and solar periods and their relationship to the interval of 11960 days.

As described above, the Maya added five extra (intercalary) days to each cycle of 162 lunar months. In other words, each 4784-day cycle contains 86 30-day and 7629 -day months ( $86 \times 30+76 \times 29=4784$ days). On average, there is one intercalation per 956.8 days. Applying the same procedure to the Eclipse Table, it gives 12.5 intercalations ( $4784 \times 2.5=11960$ days; therefore, $5 \times 2.5=12.5$ days). Simple computations imply that within each of the 11960-day cycles, there should be 215 30-day months and 190 29-day months. How can they be identified in the Eclipse Table? It is possible to identify all intercalations through the numbers of 148 or 178 days. First, there are seven 178-day semesters, referring to 7 intercalations. There are also nine groups of 148 days, each representing three months of 30 days and two months of 29 days. Those shortened semesters consisting of 5 instead of 6 months obviously overrepresent the number of 30-day months $(27 \times 30+18 \times 29=1332$ days, $45 \times 29.5=1327.5$ days). Therefore nine groups of 148 days represent only 4.5 intercalations. Those 4.5 intercalations added to 7 already identified intercalations produce 11.5 intercalations. The Eclipse Table contains therefore 11.5 intercalated days, which falls short of 11960 days by one day. However, the Eclipse Table counted from 12 Lamat to 11 Manik covers only 11959 days, so one day, more is needed to reach 12 Manik. The missing intercalary day produces 12.5 intercalations in 11960 days. This procedure agrees with the lunar data from Figure 6, where the eclipse cycles fall short of synodic cycles by 1.5 days.

As stated above, the eclipse cycle of 11960 days covers 405 lunar months grouped in sixty semesters of 6 months and nine shortened or 5-month semesters. The arrangement in regular 6-month semesters resembles much the structure of the Lunar Series, where each semester consisted of 6 numbered lunar months ruled by one of the three divine patrons. Therefore, it seems logical to expect that each 5-month group is a shortened version of the original 6-month group and that one month was dropped from a 6-month group. In this way, each shortened se- 
mester comprised the months numbered from 1 to 5 . Since there are nine groups of 5 lunar months, on each occasion, the Maya scribes subtracted one month from the supposed original 6-month group. Instead of computing the theoretical $69 \times 6$, or 414 months, the eclipse table embraces nine months less, that is, $414-9=405$ months. The „idealized” cycle of 414 months is divisible by 18 . It means it returns to the same variant of Glyph C. The „shortened” cycle of 405 months equals 22.5 runs of the 18-month cycle, producing the "recession” of Glyph C by nine positions. As a result, each run of the Eclipse Table moves back the lunar months by nine positions.

Now, if the cycle of 11960 days serves to compute the Lunar Series like is showed in the Xultun Lunar Table, then after the completion of 22 cycles of 18 lunar months (396 months) nine more months are added to arrive at 405. Contrary to the retrograde movement of Glyph $\mathrm{C}$ in the eclipse cycle, the cycle of 11960 days "moves forward” the positions of Glyph C. Since this cycle is close to the synodic cycle, each run maintains the same Moon Age. Therefore, the "rule of thumb" might determine that the cycle of 11960 days keeps the same Moon Age and moves the position of Glyph C by nine (forward or backward, depending on the type of computations $)^{6}$.

To further complicate the moon reckoning, it is important to pay attention to odd or even multiples of 11960 days. Using the "rule of thumb" described above we have

12D 5Cj $10+11960=12 \mathrm{D} 2 \mathrm{Cm} 9$,

but, if there is a even number of the multiples of 11960

12D 5 C j $10+2 \times 11960=12$ D 5 C 10

The rule seems to be simple: the odd multiples of 11960 days move the lunar month (backward or forward) by nine positions, while the even ones keep the same moon age and month.

Contrary to what one could have expected, the utility of 11960-day cycles in monumental inscriptions, might not necessarily presume intentions of eclipse predictions. Instead, it might be understood as a computing device functioning as a rule of thumb, allowing for quick computations of the Moon's recurrent phases. Figure 9 shows that one cycle 405 synodic months is about one-ninth of a day different from 11960 days, indicating an accumulated error of about one day after nine runs of the table (one day in about 295 years) ${ }^{7}$. The structure of the Xultun Lunar Table, when compared to that of the Dresden Eclipse Table, is much better equipped to agree with the lunar synodic period (compare Figures 6 and 10). It seems the Maya timekeepers were well aware of eclipse possibility cycles; nonetheless, in my opinion, they also found that the number of 11960 days was useful to compute the components of the Lunar Series. 


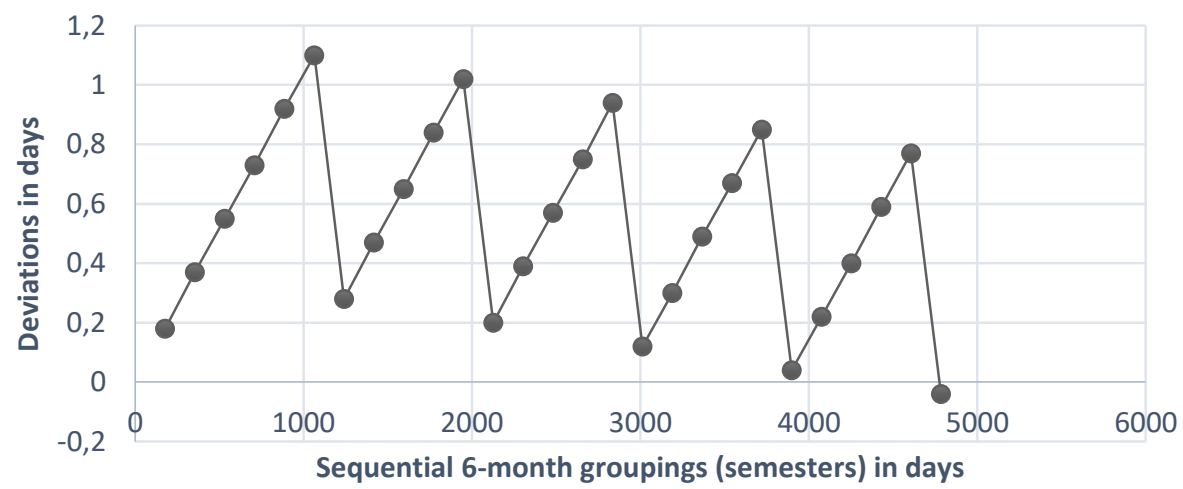

FIGURE 10a. The error in the observed and computed lunar phases, according to the Xultun Lunar Table. Once the deviation between the computed and observed dates approaches the 1-day limit, a correction is systematically adjusted. The mean accuracy of counting $27 \mathrm{x} 6$ lunar months is about 58 minutes.

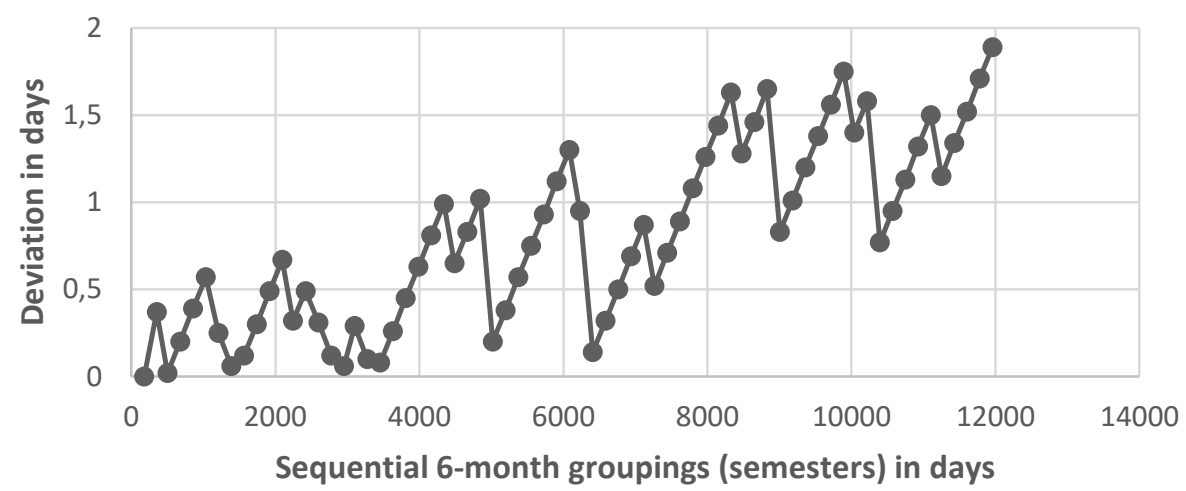

Figure 10b. The error in the observed and computed mean lunar synodic months in the Dresden Codex Eclipse Table. With the progress of the table, gradually increases disagreement with the lunar synodic month.

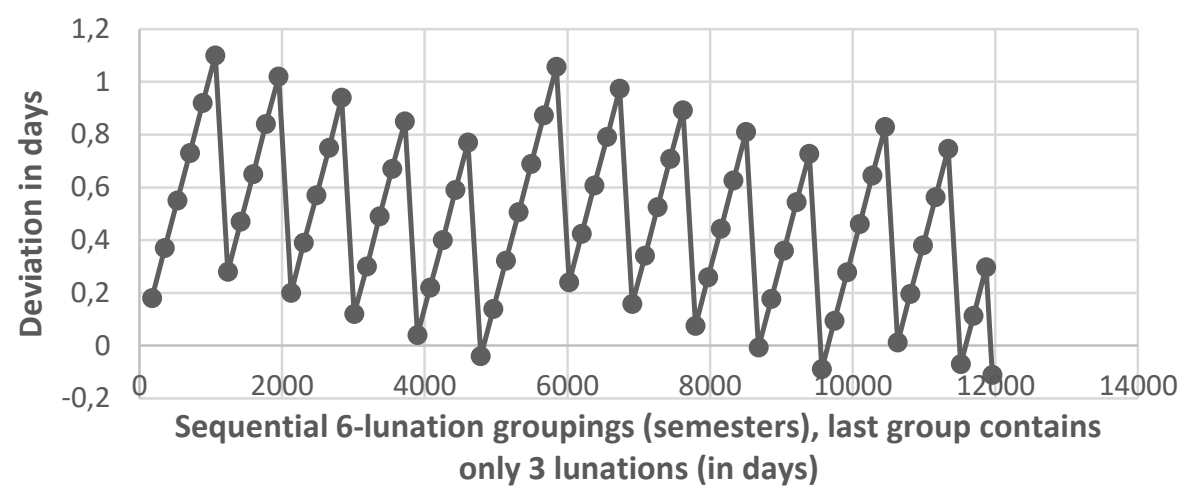

FIGURE 10c. Hypothetical 11960-day based cycle based on 2.5 runs of the Xultun Lunar Table 


\section{0-day cycles in Palenque}

With this information in mind, we can now proceed to examine 11960-day intervals contained in Palencan DNs.

About 9.15.2.7.16 9 Kib 19 Kayab (735 CE), K'inich Ahkal Mo' Nahb, the 12th ruler of Palenque and grandson of Janaab Pakal, the greatest lord of Palenque, dedicated his Temple XIX (Stuart 2005: 108). The building houses a decorated platform with two sculpted panels located on its west and south faces that contain the ruler's mythical-historical narrative. His accession date is in the passage S-7, where this event is linked, through a Distance Number, with Palenque's mythical history. The ruler took the throne on 9.14.10.4.2 9 Ik' 5 K'ayab or $721 \mathrm{CE}$ (Mathews and Schele 1974: 67-68; Stuart 2005: 15; Martin and Grube 2008: 172) and connected this date to other 9 Ik' days associated with Palenque political mythology (see Figure 11). Following the tradition already created by K'inich Kan B'ahlam, who widely used an 819-day count to link historical events with those of the Palenque Triad deities, K'inich Ahkal Mo' Nahb DNs also made direct connections with the past through numerology. In particular, utilizing the knowledge of lunar cycles, he linked his accession date and divine accessions in mythical past. The DNs linking accession dates are divisible by 11960 days, the approximation of the eclipse cycle recorded in the Dresden Codex Eclipse Table. Since the lunar synodic period inferred by Teeple (1931) from Palenque is five times smaller than the length of the Eclipse Table, the latter seems to be naturally emerging from the former.

In Figure 11. I present the sequence of all 9 Ik' dates, as is inferred from the Temple XIX platform inscriptions. The narrative starts with the accession to the rulership of GI occurred on 12.10.1.13.2 $9 \mathrm{Ik} 5 \mathrm{Mol}(3309 \mathrm{BCE})$ and the associated Lunar Series 22D 2Cj 9. The third passage gives a DN of 346840 days, or $29 \times 11960$ days, which, when added to the initial date, gives 1.18.5.3.2 $9 \mathrm{Ik} 15 \mathrm{Keh}$, the birthdate of GI. Then, a series of successive episodes leads to 2.0.0.10.2 9 Ik' 0 Sak (2325 $\mathrm{BCE}$ ), the accession date of Muwaan Mat, the progenitor of the Palenque Triad, born in $3121 \mathrm{BCE}$. The interval between those two dates amounts to $12740(11960+780)$ days. The fourth $9 \mathrm{Ik}$ date is tied to a $\mathrm{DN}$ of 111280 , or $93 \times 11960$ days that leads to 9.14.10.4.2 9 Ik' 5 K'ayab' (721 CE), the date of accession of K'inich Ahkal Mo' Nahb. These four $9 \mathrm{Ik}$ dates should serve as a starting point in testing the hypothesis about the usefulness of a 11960-day cycle for long-term lunar computations.

The importance of this interval is confirmed again in ruler's text placed on the doorjambs of Temple XVIII. There, his accession on 9.14.10.4.2 (721 CE) is connected with the inauguration of Muwaat Mat on 2.0.0.10.2 (2325 BCE) through the DS of $93 \times 11960$ days (Lounsbury 1974: 220-221). Interestingly, the text begins with the birthdate of this ruler on 9.12.6.5.8 (678 CE) together with the same Lunar Series, that was used by Teeple (see below) to infer the formula of Palenque and which bears the nonuniform system of moon reckoning. This number is both divis- 
ible by 2392 and 11960 days. As is known, John E. Teeple (1931: 54-61), who first noticed that lunar months were arranged in groups of six, proposed that between 9.12.15.0.0 and 9.16.5.0.0, or (687 - $756 \mathrm{CE}$ ), all significant sites shared the same system for numbering the coefficient of Glyph C.

He called this the „Period of Uniformity.” In general, „Uniformity” consists of computing three series of six-month periods and assigning the same numerical coefficient to Glyph C. Though later studies (see Aldana 2006: 239-240) recognized and identified earlier and later versions of uniformity, the categories of "uniformity” vs. "nonuniformity” appear to be helpful to describe the dynamics of the mechanisms employed by the Maya to count the Moon.

FIGURE 11. Chronology of selected passages of the South Panel of the Temple XIX decorated platform (after Stuart 2005: 91). Lounsbury (1976:220) first observed that the interval of 1112280 days $=93 \times 11960$ days, and Stuart (2005: 77-78) was first to notice that the DN of 346840 days equals $29 \times 11960$ days. In italic are given the Lunar Series from the Temples of the Sun and the Foliated Cross.

\begin{tabular}{|c|c|c|c|c|c|c|}
\hline $\begin{array}{l}\text { Date } \\
\text { no. }\end{array}$ & Long Count & $\begin{array}{l}\text { Calendar } \\
\text { Round }\end{array}$ & Lunar Series & Event & $\begin{array}{c}\text { Distance } \\
\text { Number } \\
\text { (days) }\end{array}$ & $\begin{array}{l}\text { Multiples of } \\
11960 \text { days }\end{array}$ \\
\hline \multirow[t]{2}{*}{1} & 12.10 .1 .13 .2 & $9 \mathrm{Ik} 5 \mathrm{Mol}$ & $22 \mathrm{D} 2 \mathrm{Cj} 9$ & $\begin{array}{l}\text { Enthrone- } \\
\text { ment of GI }\end{array}$ & & \\
\hline & +2.8 .3 .8 .0 & & & & +346840 & $29 \times 11960$ \\
\hline \multirow[t]{6}{*}{2} & $=1.18 .5 .3 .2$ & 9 Ik'15 Keh & [22D 5Cs 10] & Birth of GI & & \\
\hline & +0.0 .0 .0 .4 & & & & +4 & \\
\hline & 1.18 .5 .3 .6 & $\begin{array}{c}13 \text { Kimi } 19 \\
\text { Keh }\end{array}$ & $\begin{array}{c}\text { [26D 5Cs } 10] \\
26 \mathrm{D} 4 \mathrm{Cs}\end{array}$ & Birth of GIII & & \\
\hline & +0.0 .0 .0 .14 & & & & +14 & \\
\hline & 1.18 .6 .4 .0 & $\begin{array}{c}1 \text { Ajaw } 13 \\
\text { Mak }\end{array}$ & $\begin{array}{c}\text { [10D 6Cs 9] } \\
10 \mathrm{D} 5 \mathrm{Cs}\end{array}$ & Birth of GII & & \\
\hline & +1.15 .6 .2 & & & & +12722 & $11960+780$ \\
\hline \multirow[t]{2}{*}{3} & $=2 \cdot 0 \cdot 0.10 .2$ & 9 Ik'0 Sak & [5-6D 5Cs 10] & $\begin{array}{c}\text { Enthrone- } \\
\text { ment of } \mathrm{Mu}- \\
\text { wan Mat }\end{array}$ & & \\
\hline & +7.14 .9 .12 .0 & & & & +1112280 & $93 \times 11960$ \\
\hline 4 & $=9.14 .10 .4 .2$ & 9 Ik' 5 K’ayab & [5-6D 2Cj 9 & $\begin{array}{c}\text { Enthrone- } \\
\text { ment of Ah- } \\
\text { kal Mo' Nahb }\end{array}$ & & \\
\hline
\end{tabular}

To assist in testing this hypothesis, Figure 12 records the details of Teeple's proposal inferring the invention of the Palenque formula. Teeple compared the Lunar Series of the recorded in the Cross Group (Temple of the Cross, Temple of the Foliated Cross, and Temple of the Sun) with those of Stela 1 (Temple XVIII doorjambs) and concluded that the intervals that separated the dates from each other were reckoning lunar cycles. According to him, the Maya computed long time intervals from the base at 9.12.6.5.8 (678 CE), which he considered as being his- 
torical and therefore recording the observed lunar phase. Epigraphers have long determined the meaning of those dates. Three dates are the birthdates of patronal Palenque gods, known as the Palenque Triad (Berlin 1963; Stuart and Stuart 2008: 189-215), the fourth date denotes the birthdate of K'inich Ahkal Mo' Nahb. In sum, the deities, known as GI (not including the Lunar Series), GII, and GIII, are said to be born in November of $2360 \mathrm{BCE}$, the deity identified as Muwaat Mat, in January of 3120 BCE (consult de la Garza et al. 2012:148-169). The fourth date recorded the birth of K'inich Ahkal Mo' Nahb in 678 CE (Mathews and Schele 1974). All birthdates, the mythical and historical ones, are interconnected through Teeple's lunar formula for Palenque (see Figures 12 and 13).

$22 \mathrm{D} 2 \mathrm{Cj} 9+29 \times 11960=22 \mathrm{D} 5 \mathrm{Cs} 10+11960+780=5-6 \mathrm{D} 5 \mathrm{Cs} 10+93$ $\mathrm{x} 11960=[5-6 \mathrm{D} 2 \mathrm{Cj}$ 9]

The cycle is computed.

It is not clear why the birth of K'inich Ahkal Mo' Nahb in $678 \mathrm{CE}$, during the reign of Pakal and well before the inauguration of the Group of the Cross in 692 CE, should be connected to the birthdates of the Palenque Triad. His birthdate from Temple XVIII may not be a historical or current one because, as archaeological investigations have shown, this building was restored, rebuilt, and dedicated by K'inich Ahkal Mo' Nahb long after the dedication of the Cross Group (Mathews and Schele 1974; Ringle 1996).

It may be noticed that all lunar data cited by Teeple (1931:65) represent the non-uniform system of the lunar count. They all bear the lunar numbering system (Glyph C) that is smaller by one if matched against the Uniform system (see Figure 10). It suggests the dates could not be counted from the base at 9.12.19.14.12 $5 \mathrm{~Eb}^{\prime} 5$ K'ayab (692 CE), which denotes the inauguration of the temples, because it already adopted the uniform system of reckoning moons. It is not surprising since this last date falls within Teeple's Period of Uniformity, which started at 9.12.15.0.0 (687 CE).

Arithmetical calendrics necessarily establishes that each fixed 11960-day cycle should comprise 215 30-day months and 190 29-day months (see above, note 6). Smaller units represented by the periods of $4784+4784+2392$ days consist of 8630 -day and 76 29-day months and 4330 -day months and 38 29-day months, respectively. The structure of the 11960-day cycle is not known, so for the sake of simplicity, I assume it consisted of 2.5 cycles of 4784 -day periods. This structure fits better the requirements of the lunar count rather than of eclipse predictions. A thorough re-examination of Teeple's dates produces multiples of intervals of 11960 , 4784, 2392, 1240, 886, 354, and 177 days (see Figure 13), which also appear in the structure of the Xultun Lunar Table. However, it also suggests that the periods of 5 months (=148 days) were not used at Palenque

In connection with the lunar reckoning is the problem of intercalations. The adoption of the 11960-day cycle marks 12.5 intercalations per cycle or one intercalation per 956.8 days. The recycling of the Xultun Lunar Table produces a fixed 
FIGURE 12. The four cases examined by Teeple (1931: 65). Entries 1-4 are modified Teeple's data, entries 5-6 refer to the date of the inauguration of the Cross Group temples.

\begin{tabular}{|c|c|c|c|c|c|c|c|}
\hline No. & Monument & Long Count & $\begin{array}{l}\text { Calendar } \\
\text { Round }\end{array}$ & $\begin{array}{l}\text { Lunar } \\
\text { Series }\end{array}$ & $\begin{array}{l}\text { Lunar } \\
\text { Unifor- } \\
\text { mity }\end{array}$ & Event & $\begin{array}{c}\text { Glyphs } \\
\text { G }\end{array}$ \\
\hline 1 & $\begin{array}{l}\text { Temple of the } \\
\text { Cross Panel }\end{array}$ & $\begin{array}{l}12.19 .13 .4 .0 \\
3121 \text { BCE }\end{array}$ & $\begin{array}{l}8 \text { Ajaw } \\
18 \text { Tzek } \\
\end{array}$ & $\begin{array}{l}\text { 5D } 2 \mathrm{Cm} \\
\text { II.2 } 9\end{array}$ & $\mathrm{U}-1$ & \begin{tabular}{|l|} 
Birth of \\
Muwaat Mat
\end{tabular} & G8 \\
\hline 2 & $\begin{array}{l}\text { Temple of the } \\
\text { Sun Panel }\end{array}$ & $\begin{array}{l}\text { 1.18.5.3.6 } 2360 \\
\text { BCE }\end{array}$ & \begin{tabular}{|l}
$13 \mathrm{Kimi}$ \\
$19 \mathrm{Keh}$ \\
\end{tabular} & \begin{tabular}{|l} 
26D $4 \mathrm{Cs}$ \\
$\mathrm{I} .410$ \\
\end{tabular} & $\mathrm{U}-1$ & Birth of GIII & G3 \\
\hline 3 & $\begin{array}{l}\text { Temple of the } \\
\text { Foliated Cross } \\
\text { Panel }\end{array}$ & $\begin{array}{l}\text { 1.18.5.4.0 } 2360 \\
\text { BCE }\end{array}$ & $\begin{array}{l}1 \text { Ajaw } \\
13 \mathrm{Mak}\end{array}$ & $\begin{array}{l}10 \mathrm{D} 5 \mathrm{Cs} \\
1.39\end{array}$ & U-1 & Birth of GII & G8 \\
\hline 4 & \begin{tabular}{|l|} 
TXVIII \\
Doorjamb \\
\end{tabular} & \begin{tabular}{|l|}
9.12 .6 .5 .8 \\
$678 \mathrm{CE}$ \\
\end{tabular} & \begin{tabular}{|l}
3 Lamat \\
6 Sak \\
\end{tabular} & \begin{tabular}{|l} 
19D $5 \mathrm{Cj}$ \\
III.5 10 \\
\end{tabular} & $\mathrm{U}-1$ & $\begin{array}{l}\text { Birth of Ahkal } \\
\text { Mo' Nahb }\end{array}$ & G9 \\
\hline 5 & $\begin{array}{l}\text { Temple of the } \\
\text { Foliated Cross } \\
\text { Doorjamb }\end{array}$ & $\begin{array}{l}{[9.12 .19 .14 .12]} \\
692 \mathrm{CE}\end{array}$ & $\begin{array}{l}5 \text { Eb' } 5 \\
\text { Kayab' }\end{array}$ & $\begin{array}{l}11 \mathrm{D} 3 \mathrm{Cs} \\
\mathrm{I} .39\end{array}$ & $\mathrm{U}$ & $\begin{array}{l}\text { Inauguration } \\
\text { of the Cross } \\
\text { Group }\end{array}$ & G3 \\
\hline 6 & $\begin{array}{l}\text { Temple of the } \\
\text { Sun Doorjamb }\end{array}$ & $\begin{array}{l}{[9.12 .19 .14 .12]} \\
692 \mathrm{CE}\end{array}$ & $\begin{array}{l}\text { [5 Eb’ 5] } \\
\text { Kayab’ }\end{array}$ & $\begin{array}{l}11 \mathrm{D} 3 \mathrm{Cs} \\
\mathrm{I} .39\end{array}$ & $\mathrm{U}$ & $\begin{array}{l}\text { Inauguration } \\
\text { of the Cross } \\
\text { Group }\end{array}$ & G3 \\
\hline
\end{tabular}

scheme taking the format of 1240-886-886-886-886-1240-886-886, etc. days (consult Figure 3). Hence, my idea is that recycled 4784-day groups could serve as a tool to regularize intercalations. With this concepts, it is not surprise that computing the DNs between two dates by quickly referred intervals of $11960,4784,2392$, and 886 days, the scribes already knew how many intercalations were required. The institution of fixed rules of intercalations would have enabled Maya scribes to control computations of the lunar phases over more extended periods.

Following Teeple's lunar computations, it can be said that the birthdates of the three patron gods and K'inich Ahkal Mo' Nahb became symbolically connected through the mechanism of the Palenque lunar formula (see Figure 10). However, it is not known how the scribes performed such computations, because DNs among them do not render integral lunar cycles. Temple XIX presents us quite different situation. First, K'inich Ahkal Mo' Nahb established the link between current events and mythological past through inaugurations/rebirth occurred on $9 \mathrm{Ik}$ dates and eclipse cycles (Stuart 2005: 77-78, 85-86,183-185). The intervals between the dates are divisible by 260 days, while such dates as 3 Lamat (his birthdate, in $678 \mathrm{CE}$ ), or 8 Ajaw (birth of Muwaat Mat, in 3120 BCE), 13 Kimi (birth of GIII, in 2360 BCE), or 1 Ajaw (birth of GII, in $2360 \mathrm{BCE}$ ) are not. Second, the links between the dates of accession to the throne of K'inich Ahkal Mo' Nahb and the Palenque gods directly express multiples of 11960 days while the four cases studied by Teeple base on different intervals.

To sum up, the lunar data from Temple XIX are separated from each other as is they were arranged in 11960-day units. This fact may speak in favor of treating the 11960-day number as a formal computing unit. 
FIGURE 13. Backward computations of the lunar phases performed from the base at 9.12.6.5.8 3 Lamat 6 Sak 19D 5Cj 10 (678 CE). The intervals of days between every two dates were broken down into smaller units that have lunar meanings and might hypothetically be essential to perform quick calculations. I'm not suggesting all these units were already known to Maya timekeepers.

\begin{tabular}{|l|l|l|l|l|l|}
\hline $\begin{array}{c}\text { Dates } \\
\text { computed }\end{array}$ & $\begin{array}{c}\text { Difference } \\
\text { (days) }\end{array}$ & $\begin{array}{c}\text { The Lunar } \\
\text { Series factors } \\
\text { theoretically } \\
\text { involved }\end{array}$ & $\begin{array}{c}\text { Lunar } \\
\text { Series } \\
\text { computed } \\
\text { from date } 4\end{array}$ & $\begin{array}{c}\text { Relationship } \\
\text { between 30- } \\
\text { day and 29-day } \\
\text { months }\end{array}$ & $\begin{array}{l}\text { Intercalations } \\
\text { made }\end{array}$ \\
\hline $4-1$ & 1387108 & $\begin{array}{l}115 \times 11960+2 \\
\times 4784+(1240+ \\
886)+14\end{array}$ & 5 D 5Cm 19 & $\begin{array}{l}24935 \times 30+ \\
22036 \times 29+14 \\
\text { days }\end{array}$ & $\begin{array}{l}1449-1450 \\
\text { intercalations }\end{array}$ \\
\hline $4-2$ & 1109202 & $\begin{array}{l}92 \times 11960+3 \times \\
2392+886+708 \\
+89+23 \text { days }\end{array}$ & 26 D 4Cs 10 & $\begin{array}{l}19939 \times 30+ \\
17621 \times 29+23 \\
\text { days }\end{array}$ & $\begin{array}{l}1158-1159 \\
\text { intercalations }\end{array}$ \\
\hline $4-3$ & 1109188 & $\begin{array}{l}92 \times 11960+3 \times \\
2392+886+708 \\
+39+9 \text { days }\end{array}$ & 10 D 5Cs 10 & $\begin{array}{l}19939 \times 30+ \\
17621 \times 29+9 \\
\text { days }\end{array}$ & $\begin{array}{l}1158-1159 \\
\text { intercalations }\end{array}$ \\
\hline
\end{tabular}

As stated in Figure 13, the timekeepers who selected $9 \mathrm{Ik}$ dates to evoke an astro-numerological link between mythical and historical events, carried out lunar computations from the K'inich Ahkal Mo' Nahb's accession date in $722 \mathrm{CE}$. The lunar data associated with his enthronement are given in Temple XVIII stucco inscriptions, where Glyph D is effaced, but Glyphs $\mathrm{C}$ and $\mathrm{X}$ are legible, showing the use of the Uniform System. The date of GI's enthronement, which starts the narrative on the south face of the Platform in Temple XIX, records 22D 2Cj 10 conforming to the Uniformity. The subsequent narrative correctly identifies the birthdates of the Palenque Triad gods. First, recycling the 11960-day intervals from the initial date, the narrative arrives at the date of GI's birth. The computed lunar data appears to be 22D 5Cs 10. Both dates, the recorded and computed ones, keep the same Moon Age, while Glyph C is moved by nine positions forward. The same date of birth of GI is recorded in the Temple of the Cross, without lunar data. However, on the Temple of the Sun, the timekeepers assigned 26D 4Cs 10 for the birthdate of GIII, who was born four days later. Comparing both lunar dates, the inferred and recorded ones, I find they are consistent with both Teeple's Palenque factor of 2392 days and the Dresden Codex eclipse cycle of 11960 days (see also Teeple 1931: 69). Though their Moon Ages were calculated from different bases and probably at different times, the result remains correct. Nevertheless, the numerical coefficients of Glyph C (hereafter, Moon Numbers) refer to two different months, mirroring lunar Uniformity and non-Uniformity. The Moon Numbers attached to the birthdates of the Palenque Triad gods discussed by Teeple (1931:65) are smaller by one if compared with the Uniform System. It seems the Maya timekeepers attempted to articulate connections between K'inich Ahkal Mo' Nahb and GI in basically the same way as Teeple 
proposed in the previous calculation. However, their assigned Moon Numbers following the uniform system rather than the non-Uniform one.

The four cases studied by Teeple do not harmonize with the Uniform System. However, the Uniform System was evidently in use at Palenque at least, since the inauguration of the Temple Olvidado in 647 CE still by Janaab Pakal (Berlin 1943). This discrepancy in assignments of Moon Numbers needs some explication. As stated above, the Uniform System consists of regular groupings of six lunar months, and the computations performed through DNs appear to confirm this structure. Eclipse cycles, on the other hand, involve occasional five-month groupings. The Moon Number lowered by one, as appears at the birthdate of K'inich Ahkal Mo' $\mathrm{Nahb}$ when compared to his accession date, may indicate that one five-month interval was introduced. That is, one six-month group was shortened to five months. Therefore, the difference in Moon Numbers would be indicative of an eclipse cycle. It seems unlikely that the timekeepers used two parallel systems of regular sixmonth groupings that differed by one position

My suggestion means that the 11,960-day cycle accounts in the Palenque texts do not refer to the prediction of eclipses but the Lunar Series. Mayan scribes may have used this interval to quickly calculate the Moon's age and the coefficients of Glyph C in the distant past (see above, note 6).

On pages 51a and 52a, there is a table of multiples of 11960 days (see Figure 14). These multiples are arranged in seven columns; six columns contain two numbers, one written in black and one written in red, while the leftmost column contains only one number, written in black. The table provides 1,2,3 (twice), 4, 5, 6, $16,17,18,31$, and 39 multiples of 11960 , in three cases the numbers are accompanied by other numbers $(1 \times 11960+1820$ days; 6 × $11960+120$ days, $31 \times 11960+$ 260 days). All added numbers are divisible by 20 , conserving the same tzolk'in day name. Bricker and Bricker (2011:252) propose the multiples and added intervals could have served as correction factors for recycling the table. None of the multiples examined in DNs from Palenque ( $29 \times 11960,11960+780$, and $93 \times 11960)$ coincides with the data from the table of multiples. Possible those multiples were not useful to forecast eclipse possibilities. If so, this fact may argue against the use of 11960-day cycles in DNs to eclipse predictions.

In my opinion, this discussion should suffice to treat the DN multiples of 11960 days as computing devices to perform lunar computations rather than to forecast eclipses.

\section{Conclusions}

The Xultun Lunar Table functions in relation to the phases of the Moon. The sequence of the months commensurates with the lunar synodic month. On the other hand, the Dresden Codex Eclipse Table is structured to predict eclipse 
possibilities. However, to recycle this table, it is necessary to design some corrective mechanisms. Aside from eclipse predictions, the table may also function to count lunar synodic months (405). The 11960-day interval found in DNs at Palenque equals the length of the eclipse table, but its use to forecast eclipses is not functional unless some corrective mechanisms are applied. Therefore, it is possible that this number commensurates with the $2.5 \times 4784$ day $=11960$-day cycle associated with the computation of the lunar synodic period. Its insertion into DNs is, therefore, functional, allowing for quick computations of the lunar phases.

\section{Notes}

1 In this paper I have followed the following spelling convention. The language of the Dresden Codex is close to the Colonial Yucatec so the names of tzolk'in are given in Yucatec Mayan language of the $16^{\text {th }}$ century (Velásquez García 2016). The proper names of tzolk'in days and rulers of Palenque follow the spelling conventions of De la Garza et al. 2012.

2 John Linden $(1986,1996)$ was first to notice that Glyphs X variants might be correlated with the coefficients of Glyph C and proposed the development of a larger eighteen-month count. His discoveries were later confirmed by Linda Schele, Nikolai Grube, and Federico Fahsen (1992). A similar conclusion was reached by Jens Rohark (1996), who proposed that each form of Glyph X corresponded to one of the eighteen months described by the coefficients of Glyph C. The formal table displaying eighteen lunar months having either 29 or 30 days was first proposed by Iwaniszewski (2010).

3 The idea that the Moon might cover the view of the Sun and hence cause an eclipse appears to be a Colonial rather than a prehispanic one (see Craine and Reidorp 1979:50; Sánchez de Aguilar 1953: 276). However, the Maya understood well how to predict eclipse possibilities (see Iwaniszewski 2018).

4 One possible exception is a reference to a solar eclipse is found on Stela 3 at Santa Elena Poco Uinic, another possibility offers the interpretation of the lintel from the Monjas (Nunnery) annex from Chichén Itzá (Milbrath 1999: 115; Bricker and Bricker 2011: 364). The structure of the Lunar Series, arranged in the sequence of three semesters of six lunar months each, may also suggest it originated from the observations of the eclipse half-year of 173.31 days. Eclipse intervals recorded in historical texts discussed in this paper may also indicate some potential for the prediction of eclipses, but their links with observed eclipses must still be demonstrated.

5 Bricker and Bricker (1992) set out a particular methodology to demonstrate how the eclipse table could be tied to historical dates. Both Robert Smither (1986) and John Justeson (2017) attempted to find patterns of visible eclipses in prehistoric Mesoamerica that could give the structure to the Dresden Eclipse Table. In light of those recent developments, it is appropriate to conclude that the Dresden Codex Eclipse Table announces eclipse possibilities and not that an eclipse was currently going on.

6 The computing scheme suggested here supposes that the 11,960-day cycle found in Palenque texts does not refer to the eclipses' prediction but the Lunar Series. Mayan scribes may have used this interval to quickly calculate the Moon's age and the coefficients of Glyph $\mathrm{C}$ in the distant past. This number implies the following relationships:

1. A mean synodic month $=29.5308642$ days.

2. It consists of 405 schematic 29-day and 30-day months. It comprises 215 months of 30 days each and 190 months of 29 days each $(215 \times 30+190 \times 29=11960)$.

3. Two rounds of 11960 days return in both the numerical coefficient and head variant of Glyph C because $2 \times 405$ months $=810$ months, and 810 is divisible by 18 without rest. One cycle of 11960 days moves both coefficients by nine positions, either backward or forward (depending on the context).

4. Because the Maya lunar month is determined by a mechanical alternation of 29-day and 30day units, the lunar record expressed by the Lunar Series continuously shifts about the synodic Moon. It is easy to infer that within two cycles of 11960 days (23920 days), 25 days are interca- 
lated to keep up with the lunar synodic period (there are 430 months of 30 days each and 380 months 29 days each).

$7405 \times 29.530589=11959.889$ days, $46 \times 260=11960$ days, then the difference between both cycles amounts to 0.11145 days. Hence, $(0.11145$ days $\approx 2$ hours 40 minutes and 29 seconds $)$ x $9=1$ day 4 minutes 211 seconds. (11960 days $=32$ years and 272.25 days $) \times 9=294$ years 259 days. $(11960 \mathrm{x}$ 9): $365=294$ years 330 days. Observe that $(11960 \times 9)=360 \times 299$, that is, after nearly 15 katuns, or 14.19.0 days, 1-day correction was needed (consult Lounsbury 1978: 796-797).

\section{References}

Aldana, Gerardo V.

2006

Lunar Alliances: Shedding Light on Conflicting Classic Maya Theories of Hegemony. In: Viewing the Sky Through Past and Present Cultures, Todd W. Bostwick and Bryan Bates (eds.). [Pueblo Grande Museum Anthropological Papers, No. 15], pp. 237-258. City of Phoenix Parks and Recreation Department, Phoenix.

2007 The Apotheosis of Janaab' Pakal: Science, History, and Religion at Classic Maya Palenque. Boulder, University Press of Colorado.

Barthel, Thomas S.

1951 Maya-Astronomie. Lunare Inschriften aus dem Südreich. Zeitschrift für Ethnologie, 76: 216-238.

Berlin, Heinrich

1963 The Palenque Triad. Journal de la Societé des Américanistes, 52: 91-99. Beyer, Hermann

1933 Zur Konkordanzfrage der Mayadaten mit denen der christlichen Zeitrechnung. Zeitschrift für Ethnologie, 65: 75-80.

1935 On the Correlation between Maya and Christian Chronology. Maya Research, 2, 1: 64-72.

1937 Lunar Glyphs of the Supplementary Series at Piedras Negras. El Mexico Antiguo 4, 3-4: 75-81.

Brauer, Teutomar

2007 A New Approach for Systemizing the Dates in the Maya Lunar Series. Mexicon 29, 4: 99-102.

Bricker, Victoria R. , and Harvey M. Bricker

1992 A Method for Cross-Dating Almanacs with Tables in the Dresden Codex. In The Sky in Mayan Literature, edited by Anthony F. Aveni, pp. 43-86. Oxford University Press, New York.

Bricker, Harvey M., and Victoria R. Bricker 2011 Astronomy in the Maya Codices. [Memoirs of the American Pholosophical Society, 265]. American Philosophical Society, Philadelphia.

Craine, Eugene R. and Reginald C. Reindorp

1979 The Codex Perez and The Book of Chilam Balam of Mani. University of Oklahoma Press, Norman. 
De la Garza, Mercedes, Guillermo Bernal Romero and Martha Cuevas García

2012

Palenque-Lakamha'. Una presencia inmortal del pasado indígena. Fondo de Cultura Económica, El Colegio de México and Fideicomiso Historia de las Américas, México.

Guthe, Carl E.

1921 A Possible Solution of the Number Series on pages 51 to 58 of the Dresden Codex. Papers of the Peabody Museum of American Archaeology and Ethnology, Harvard University, Vol. Vi, no. 2. Peabody Museum, Cambridge, Mass.

Iwaniszewski, Stanislaw

2004 Glyphs D and E of the Lunar Series at Yaxchilán and Piedras Negras. Archaeoastronomy. The Journal of Astronomy in Culture 18 (2004): 6780.

2007 Glyphs E and D in the Lunar Series from Quirigua, Guatemala and Copan, Honduras. In: Archaeoastronomy in Archaeology and Ethnography (papers from the annual meeting of SEAC held in Kecskemét in Hungary in 2004, edited by Emília Pásztor, pp. 149-159. BAR International Series 1647, Archaeopress, Oxford.

2010 Las relaciones políticas a través de las Series Lunares en las inscripciones de Calakmul y sus alrededores. In Memorias del XVIII Encuentro Internacional de Los Investigadores de la Cultura Maya. Tomo II: 97-110. Universidad Autónoma de Campeche, Campeche 2018 ¿Cómo predecir eclipses en 20 minutos? La Tabla de Eclipses del Códice de Dresde". In Libros sagrados mayas de tierras bajas de las épocas prehispánica y colonial, edited by Erik Velásquez García y Florencia Scandar. Instituto de Investigaciones Estéticas, Universidad Nacional Autónoma de México, México (submited for publication).

2020 The use of the Palenque ratio in the Lunar Series as a means to preserve the legitimacy of the ruling dynasty of the Palenque kingdom. In Harmony and Symmetry: celestial regularities shaping human culture. Proceedings of the SEAC 2018 Conference in Graz, edited by Sonja Draxler, Max E. Lippitsch and Gudrun Wolfschmidt, pp. 358364.Tredition, Hamburg.

Justeson, John S.

1989 Ancient Maya ethnoastronomy: an overview of hieroglyphic sources. In World Archaeoastronomy, edited by Anthony F. Aveni, pp. 76-129. Cambridge University Press, Cambridge.

2017 A Cyclic-Time Model for Eclipse Prediction in Mesoamerica and the Structure of the Eclipse Table in the Dresden Codex. Ancient Mesoamerica 28, 2: 507-541. 
Linden, John H.

1986 Glyph X of the Maya Lunar Series: An Eighteen-Month Lunar Synodic Calendar. American Antiquity 51, 1: 122-136.

1996 The Deity Head Variants of Glyph C. In Eighth Palenque Round Table, 1993, edited by Martha J. Macri and Jan McHargue, pp. 343-356. [General Editor: Merle Greene Robertson], The Pre-Columbian Art Research Institute, San Francisco.

Lounsbury, Floyd G.

1974 The Inscription of the Sarcophagus Lid at Palenque. In Primera Mesa Redonda de Palenque, Part II. Edited by Merle Greene, Robertson, pp. 5-19. Pre-Columbian Art Research, The Robert Louis Stevenson, School, Pebble Beach, Cal.

1976 A Rationale for the Initial Date of the Temple of the Cross at Palenque. In The Art, Iconography \& Dynastic History of Palenque, Part III. The Proceedings of the Segunda Mesa Redonda de Palenque, edited by Merle Greene Robertson, pp. 211-224. Pre-Columbian Art Research, The Robert Louis Stevenson, School, Pebble Beach, Cal. Maya Numeration, Computation, and Calendrical Astronomy. In Dictionary of Scientific Biography, vol. 15, suppl. 1, edited by Charles Coulston Gillespie, pp. 757-818. Charles Scribner's Sons, New York. 1980 Some Problems in the Interpretation of the Mythological Portion of the Hieroglyphic Text of the Temple of the Cross at Palenque. In Third Palenque Round Table, 1978, Part 2, edited by Merle Greene Robertson, pp. 99-115. University of Texas Press, Austin.

Mathews, Peter and Linda Schele

1974 The Lords of Palenque: The Glyphic Evidence. In Primera Mesa Redonda de Palenque, Part 1. Edited by Merle Greene Robertson. Robert Louis Stevenson School, Pebble Beach, pp. 63-76.

Milbrath, Susan

1999 Star Gods of the Maya: Astronomy in Art, Folklore, and Calendars. University of Texas Press, Austin.

Ringle, William M.

1996 Birds of a Feather: The Fallen Stucco Inscription of Temple XVIII, Palenque, Chiapas. In Eighth Palenque Round Table, 1993, edited by Martha J. Macri and Jan McHargue, The Pre-Columbian Art Research Institute, San Francisco, pp. 45-62.

Rohark, Jens

1996 Die Supplementärserie der Maya. Indiana 14: 53-84.

Sánchez de Aguilar, Pedro

1953 Informe contra los adoradores de ídolos del Obispado de Yucatan año de 1639. In Tratado de las idolatrias, supersticiones, dioses, ritos, 
hechicerias y otras costumbres gentilicas de las razas aborigenes de Mexico. Edited and comented by Francisco del Paso y Troncoso, pp. 181-336. Ediciones Fuente Cultural, México.

Satterthwaite, Linton

1947 Concepts and Structures of Maya Calendrical Arithmetics. Joint Publications of the University of Pennsylvania Museum and the Philadelphia Anthropological Society, No. 3. Philadelphia.

Schele, Linda, and David Freidel 1990 A Forest of Kings: The Untold Story of the Ancient Maya. William Morrow, New York.

Schele, Linda, Nikolai Grube, and Federico Fahsen

1992 The Lunar Series in Classic Maya Inscriptions: New Observations and Interpretations. Texas Notes on Precolumbian Art, Writing, and Culture No.2'9.

Smither, Robert K.

1986 The 88 Lunar Month Pattern of Solar and Lunar Eclipses and Its Relationship to the Maya Calendars. Archaeoastronomy, The Journal of the Center for Archaeoastronomy 9: 99-113.

Stuart, David y George Stuart

2008 Palenque: Eternal City of the Maya. Thames and Hudson, London.

Stuart, David

2005 The Inscriptions from Temple XIX at Palenque. The Pre-Columbian Art Research Institute, San Francisco.

Teeple, John

1928 Lunar Inscription VI: The Lunar Calendar and Its Relation to Maya History. American Anthropologist 30(3): 391-407.

1931 Maya Astronomy. Publication 403, Carnegie Institution of Washington, Washington.

Velásquez García, Erik

2016 Códice de Dresde, introducción, e interpretación de láminas. Arqueología mexicana 67

Villacorta C., J. Antonio and Carlos A. Villacorta

1930 Códices mayas, reproducidos y desarrollados. Tipografía Nacional, Guatemala. 
